\title{
Euharistie și martiriu - evenimente ecleziale în misiunea Bisericii
}

\author{
Răzvan BRUDIU*
}

Abstract: Christ's sacrifice, the confessor sacrifice of martyrs and of the Eucharistic sacrifice are in a close interdependence. Christ is the Archmartyr par excellence because His death is a martyr's death, the Cross is a terrible martyric ordeal. Martyrs are those who testify to the whole world for the Church of Christ, where they remain through the sacrifice of their own lives. They are those who die for their faith and thus become witnesses of faith, of the power of the soul over the body and the power of resurrection over death. Martyrs are those who have offered their lives to Christ as a well received sacrifice, showing to the world that they did not want to save their lives or to obtain certain social or personal benefits, recognizing that the human soul is more precious than the whole world. Martyrs are a symbol for the whole Christian religion because for them the teaching of Christ was not just a set of theoretical notions, but a living and life-giving word. The dynamism of the Church is accomplished

* PhD, Faculty of Orthodox Theology at „1 Decembrie 1918” University in Alba Iulia, Romania. 
by the living and non sacrificed sacrifice, meaning the dead and risen Christ. Eucharist is not just a symbol of a fact that occurred sometime in history, but is itself the eschatological reality of a world that began concomitant with the Mystical Supper and continues until the end of ages. The Eucharist holds an eschatological dimension as by it man lives with and in Christ. It gives man real and personal contact with Christ, making him live yet from the earth this eschatological life.

Keywords: martyr, confession, faith, eschatology, Eucharist, relics.

\section{Introducere}

Termenul martir are ca fundament Sfânta Scriptură, considerându-L pe Hristos ca fiind Martorul suprem al credinţei: ,Iisus Hristos, Martorul cel credincios, Cel întâi-născut din morţi şi Domnul împăraţilor pământului; Lui, Care ne iubeşte şi ne-a dezlegat pe noi din păcatele noastre prin Sângele Său”; ,Ingerului Bisericii din Laodiceea scrie-i: «Acestea zice Cel ce este Amin, Martorul cel credincios şi adevărat, începutul zidirii lui Dumnezeu»" (Apocalipsa 1, 5; 3, 14), astfel încât martirii şi mărturisitorii tuturor vremurilor ce au urmat sunt urmaşii direcţi şi legitimi ai Arhimartirului Hristos. Martiriul aparţine în esenţa lui Bisericii, pentru că în ea apare moartea şi învierea creştină prin excelenţă².

Martirii primelor secole creştine aveau puterea unei credinţe mărturisitoare, aşa încât ei doreau să se aducă jertfă bineprimită lui Dumnezeu: „sanctuarele martirilor sunt splendide, impozante prin grandoare, atrăgând toate privirile celor din jurul lor. Creştinii de atunci îi cereau Stăpânului martirilor, adică lui Hristos, ca cei buni să-şi păstreze sănătatea şi cei care luptă impotriva bolilor să li se ia suferinţele. Soţii care n-au copii îi cer, femeile sterpe se roagă să devină mame, în timp ce acei care au acest privilegiu se roagă să-l păstreze. Călătorii care vor să plece departe îi roagă pe sfinţii martiri să-i însoțească şi să le arate drumul. Nu li se închină precum zeilor, dar îi invocă precum oameni ai lui Dumnezeu şi îi roagă să le fie ambasadori. Şi cei care se roagă cu credinţă primesc

\footnotetext{
${ }^{2}$ Karl Rahner, Herbert Vorgrimler, Dizionario di Teologia, edizione italiana a cura di Giuseppe Ghiberti e Giovanni Ferretti, by Herder-Roma, 1968, p. 374.
} 
ceea ce cer. Prin credinţă aceşti oameni mărturisesc puterea martirilor care se odihnesc, putere care arată că Dumnezeul lor este cel adevărat"’.

Prin persecutarea creștinilor, acest dar a fost dat martirilor care au acceptat de bunăvoie moartea, deoarece credința stă mărturie puterii harului care a transformat suferința lor în bucurie. Astfel, ei au arătat biruința lui Hristos asupra morții și propria lor adopție de către Hristos. În acest sens, martiriul este o continuare, dar și un rezultat, al apostolatului din lume. Când primim Sfânta Euharistie, auzim în cuvintele rugăciunii făgăduința lui Hristos Care zice: „Cel ce mănâncă trupul Meu și bea sângele Meu, rămâne intru Mine și Eu intru el" (Ioan, 6, 56). Când reflectăm la cuvintele tainice ale Trupului și Sângelui Sfânt, ar trebui să ne gândim la ceea ce înseamnă exact atunci când Dumnezeu este $\hat{\imath}$ noi și noi suntem $\hat{\imath} n \mathrm{El}^{4}$.

Trupul și Sângele lui Hristos sunt termenii reali ce alcătuiesc ipostaza de har-dar a dragostei lui Dumnezeu pentru oameni. Euharistia este cea care îi cheamă pe oameni să-și însușească darul în termenii existenței reale, care constituie o premisă a existenței, în termenii mâncatului și băutului. În Euharistie ni se oferă darul-harul eliberării de creaţie, în termenii întrupării reale a darului (Trupul și Sângele lui Hristos), ca mâncare și băutură, adică premisă vitală a existenței reale. Hrană împărtășită, împărtășirea pâinii și a vinului, toate acestea sunt împărtășite la Euharistia Bisericii: este împărtășită hrana (pâinea și vinul) ca referință reală la modul în care Fiul își împărtășește existența cu Tatăl. Tocmai acest mod redă ipostaza întrupării Fiului; este Trupul și Sângele lui Hristos: realitatea existențială a eliberării de limitările creațieis .

${ }^{3}$ Théodoret de Cyr, Thérapeutique des maladies helléniques, „Sources Chrétiennes”,
No 57. 2, Tome II (Livres VII-XII), Texte critique, traduction, notes et index par
Pierre Canivet, Paris, Les Éditions du Cerf, 2001, pp. 333-334.
${ }^{4}$ Laurentius Sobco, Noul Martiriu: un scurt moment de eroism sau un mod de viață,
în „Eucharist and Martyrdom, From the Ancient Catacombs to the Communist
Prisons”, Alba Iulia, 6-8 may 2014, Editura Reîntregirea, pp. 156-157.
${ }^{5}$ Christos Yannaras, Contra Religiei, trad. Tudor Dinu, București, Editura 


\section{Martor, mărturie și martiriu în viața Bisericii}

În viziunea teologică, martiriul este sinonim cu botezul sângelui, ca act al iubirii mărturisitoare, şi întăreşte Tainele Bisericii, fiind manifestarea unei stări pline de har, pe care Dumnezeu o dă omului ca dar. Moartea de bunăvoie este acceptată de Biserică drept mărturie, de la începuturile ei şi până în zilele noastre ${ }^{6}$. În acest sens, martiriul Sfinţilor Apostoli Petru şi Pavel este de netăgăduit, şi în acelaşi timp, grăitor pentru noi creştinii: „Petru, care, din pricina unei gelozii nedrepte, n-a suferit una, nici două, ci mai multe chinuri; şi după ce a dat astfel mărturie [de martir], a plecat la locul de slavă datorat lui. Din pricina unei gelozii şi a unei sfădiri, a primit şi Pavel premiul răbdării, purtând de şapte ori lanţuri, fugar şi lovit cu pietre, ajungând un crainic atât în Răsărit, cât şi în Apus, a primit faima nobilă a credinţei lui... Şi aşa s-a eliberat de lumea aceasta şi s-a dus în locul cel sfânt, făcându-se o foarte mare pildă de răbdare"”.

În martiriu, credinţa mărturisitoare lucrează ca o energie, precum credinţa într-un $T u$, împreună lucrând cu $E l$. Martiriul este aşadar o împreună lucrare cu Dumnezeu. El nu este o ideologie sau un concept, ci întreaga credință ca viață, fundamentată pe întâlnirea cu Tu-ul divin, care se manifestă prin şi cu iubire faţă de oameni. Martiriul ca expresie a iubirii faţă de Dumnezeu, prin care cineva se lasă lipsit de viaţă, şi prin a cărui Iubire ştie să suporte durerea acceptării sacrificiului, arată dimensiunea eshatologică a Bisericii în lume ${ }^{8}$. Epistola către Diognet este documentul care explică strategia mărturiei şi mărturisirii credinţei din perioada apostolică: „Nu vezi că sunt aruncaţi la fiare, ca să tăgăduiască pe Domnul, şi nu sunt învinşi? Nu vezi că, pe cât sunt pedepsiţi mai mult, pe atât se înmulţesc? Acestea nu par fapte de om, acestea sunt o putere

Anastasia, 2011, pp. 110-111.

${ }^{6}$ Karl Rahner, Herbert Vorgrimler, op.cit., p. 374.

${ }^{7}$ Ioan I. Ică jr, Canonul Ortodoxiei, Canonul apostolic al primelor secole, I, Sibiu, Editura Deisis, 2008, p. 397.

${ }^{8}$ Autori vari, La prassi del martirio ieri e oggi, Quaderni ASAL, nuova serie, Anno I, numero 3, maggio-giugno, periodico bimestrale della cooperativa „Servizio Missionario”, 1978, p. 13. 
a lui Dumnezeu, acestea sunt o dovadă a prezenței Lui"”.

Scrisoarea către Romani a Sfântului Ignatie din Antiohia şi cea a Martiriului Sfântului Policarp sunt două trimiteri la moartea sfinţilor şi la cinstirea sfintelor moaşte. Scriindu-le romanilor, el îi îndeamnă pe creştinii de acolo să nu îl oprească din lupta sa cu bestiile sălbatice din arenă, îndemnându-i: ,„ă convingă fiarele sălbatice, ca ele să devină mormântul meu, să nu lase nimic din trupul meu, ca nu cumva să rămân o povară pentru cineva după adormire"10.

Didascalia Apostolilor îi îndeamnă, de asemenea, pe creştini ,„s̆ se adune, chiar şi în cimitire, şi să citească Sfintele Scripturi ... şi să îşi indeplinească sarcinile ... şi să dăruiască Sfânta Euharistie" ". . Aceeaşi lucrare precizează faptul cum că trupul profetului Elisei (Regi 2,13) a înălţat trupul unui alt mort, datorită păstrării prezenței Sfântului Duh în trupul său mort. Creştinii ortodocşi cred, de asemenea, că Sfântul Duh continuă să sălăşuiască în trupurile celor sfinţi. Totodată, având în vedere faptul că sfinţenia nu este oficial acordată (recunoscută) decât după studierea adecvată a vieţii unei persoane, întreprinsă după moartea acesteia, trebuie să treacă un răstimp de la îngroparea unei persoane sfinte şi până la canonizarea şi recunoaşterea trupului ca fiind sfinte moaşte ${ }^{12}$. Venerarea moaştelor este, în fond, un mod de a se asigura faptul că toţi sfinţii sunt veneraţi în rândul credincioşilor şi că, în schimb, credincioşii admit faptul că harul divin lucrează în aceşti sfinţi şi după moarte, ca un dar pentru Biserică.

Constituţiile Sfinţilor Apostoli prin Clement, referindu-se la martiri, ne spun că: „Cel ce s-a invrednicit de martiriu să se bucure in

\footnotetext{
${ }^{9}$ Ioan I. Ică jr, op. cit., p. 385.

${ }^{10}$ Michael W. Holmes, The Apostolic Fathers in English, Grand Rapids, MI: Baker Academic, p. 114.

${ }^{11}$ Didascalia Apostolorum, http://www.bombaxo.com/didascalia.html (accesat în 28. 06. 2015).

${ }^{12}$ Kathryn Wehr, The Orthodox Bioethics of Cremation in http://www. orthodoxytoday.org/OT/view/wehr-the-orthodox-bioethics-of-cremation (accesat în 29. 06. 2015).
} 
Domnul întrucât a dobândit o asemenea cunună şi şi-a făcut ieşirea din viaţă prin mărturisire. Şi dacă e catehumen, să plece neîntristat, căci pătimirea pentru Hristos va fi pentru el un botez mai adevărat, fiindcă el a murit prin experienţă impreună cu Domnul, iar ceilalţi în prefigurare"13.

În Constituţiile Apostolice apare ideea martirajului creştin şi a solidarităţii pe care creştinii trebuie să o arate faţă de aceşti martori ai morţii şi învierii lui Hristos: „De aceea, toţi credincioşii, prin intermediul episcopului, recunosc toate aceste binefaceri şi rodul muncii voastre; acela care n-are nimic şi care pune hrana zilei deoparte, o rezervă sfinţilor, dacă cineva trăieşte in abstinență acela î ajută pe cei din urmă, dându-le importanţă, şi dacă cineva îi poate elibera pe sfinţi din inchisori va deveni preafericit şi prieten al Lui Hristos. Căci cei care cunoscând lucrurile duhovniceşti, şi îşi oferă bunurile lor, aceştia sunt demni de Dumnezeu şi Îi împlinesc voinţa salvându-i pe cei care Îl mărturisesc pe El în faţa naţiunilor, demnitarilor ... Căci dacă veţi face asta va rămâne ca un martiriu. De fapt, martiriul devine experienţă, şi pentru voi voinţa va fi asociată cu lupta lor"'14.

În Istoria bisericească, Eusebiu de Cezareea subliniază faptul că martirii au devenit adepţii şi imitatorii lui Hristos. Prin martiriu, ei nu au vrut să ajungă la o posibilă egalitate cu Dumnezeu, ci la măsura vârstei deplinătăţii lui Hristos. Sfinţii, care erau chinuiţi, bătuţi, arşi, striviţi de fiare sălbatice, nu doar că nu s-au autointitulat cu numele de martiri, dar nici n-au permis celorlalţi să folosească acest apelativ, şi dacă, totuşi, vreunul dintre ei îl întrebuinţa, i se răspundea cu amărăciune. Se dorea ca acest nume să fie rezervat doar pentru Hristos, Martir fidel şi personal, primul născut între morţi, „,Prinţul vieţii’, de către Dumnezeu ${ }^{15}$. Ei îşi aminteau de martirii care erau deja plecaţi din aceată lume şi spuneau: aceştia sunt deja martirii pe care Hristos i-a îndreptăţit ca mărturisitori, după ce le-a conferit prin

\footnotetext{
${ }^{13}$ Ioan I. Ică jr, op.cit., p. 673.

${ }^{14}$ Les Constitutions Apostoliques, „Sources Chrétiennes”, No 329, Tome II (Livres III-VI), Introduction, texte critique, traduction et notes et index par Marcel Metzger, Paris, Les Éditions du Cerf, 1986, pp. 203-204.

${ }^{15}$ Eusèbe de Césaré, Histoire Ecclésiastique, „Sources Chrétiennes”, No 41, Livres V-VII, Traduction et notes par Gustave Bardy, Paris, Les Éditions du Cerf, 1955, pp. 23-24.
} 
moarte pecetea martiriului; cât despre noi, noi nu suntem decât nişte umili mărturisitori. $\mathrm{Cu}$ lacrimi, prin plâns, ei i-au îndemnat pe fraţii lor şi le-au cerut să se roage cu tărie pentru trecerea lor din această lume. Ei arătau prin fapte puterea martiriului având printre păgâni o libertate deplină a limbajului şi arătând prin răbdarea lor nobleţea sufletului, curajul şi fermitatea lor $^{16}$.

Sfântul Ciprian al Cartaginei este cel care a dezvoltat o adevărată teologie a martiriului continuu ${ }^{17}$. Datorită lui s-a răspândit idealul ascezei ca prelungire a martiriului, ideal care urma să fie încununat prin împlinirea poruncilor şi supunerea faţă de ele ${ }^{18}$. Martiriul nu depinde de om, ci de harul divin, şi pentru că este un dar, nu poate fi căutat; omul nu poate decât să-l primească atunci când îi este pus înainte ${ }^{19}$. Este adevărat că în perioada Sfântului Ciprian se recurgea adesea la substantivul corona şi la verbul coronare atunci când se vorbea despre martiriu. Corespondenţa sa atestă acest fapt în mod constant ${ }^{20}$. Folosirea creştină a metaforei cununei menită să desemneze recompensa promisă creştinilor fideli derivă din textul Sfântului Apostol Pavel: ,Şi oricine se luptă se înfrânează de la toate. Şi aceia, ca să ia o cunună stricăcioasă, iar noi, nestricăcioasă" (I Corinteni 9, 25).

Sfântul Ioan Gură de Aur, vorbind despre martiri, vine şi oferă creştinilor o explicaţie a amânării justiţiei divine faţă de păgâni. Minunile săvârşite de apostoli după moartea şi învierea lui Hristos dovedesc faptul că puterea Sa rămâne prezentă în această lume. Această putere se manifestă şi prin martiri: „Cea mai mare dovadă a

${ }^{16}$ Ibidem, p. 24.

${ }^{17}$ Saint Cyprien de Carthage, La bienfaisance et les aumônes, „Sources Chrétiennes", Introduction, texte critique, traduction par Michel Poirier, Paris, Les Éditions du Cerf, 1999, p. 193.

${ }^{18}$ Ibidem.

${ }^{19}$ Jean Claude Larchet, Sfârşit creştinesc vieţii noastre, fără durere, neînfruntat, in pace..., trad. Marinela Bojin, Bucureşti, Editura Basilica a Patriarhiei Române, 2012, pp. 51-52.

${ }^{20}$ Saint Cyprien de Carthage, op.cit., p. 194. 
Invierii este faptul că după moartea Sa, Hristos manifestă şi dezvoltă o putere asemănătoare celei care-i convinge pe creştini să renunţe la ţara lor, la casa lor, la prietenii lor, la părinţii lor, la însăşi viaţa lor pentru a o mărturisi. Această putere îi determină pe aceşti oameni să aleagă bicele, pericolele şi moartea $\hat{\imath}$ detrimentul plăcerilor de moment ... Acestea nu sunt faptele unui trup mort culcat şi aşezat într-un mormânt, ci sunt faptele unui înviat, ale unui om viu"21.

Pentru a îndemna la bucurie şi stăruinţă în credinţă pe creştinii, care aidoma martirilor îşi declaraseră credinţa în faţa autorităţilor care îi persecutau, fără însă a le vărsa sângele, Sfântul Ciprian scrie următoarele: ,Mărita noastră Biserică... Innainte purtarea fraţilor îi părea că are culoarea inocenţei. Azi, sângele martirilor revarsă culoare purpurie. Nici crinii, nici trandafirii nu-i seamănă. Cât despre dorinţă, fiecare se străduieşte să atingă demnitatea supremă a celor două stări onorabile: căci toți primesc cununi: fie albe pentru faptele lor bune, fie roşii pentru suferinţele lor"22.

Jertfele martirilor sunt revelarea conţinutului Sfintei Euharistii. Moartea acestora semnifică faptul că adevărul tainic acuns în viaţa sacramentală a Bisericii este o putere vivificatore care zdrobeşte moartea, este dinamismul stării permanente de jertfă a lui Hristos, este iubirea lui Dumnezeu care se întâlneşte cu iubirea omului în Biserică prin Euharistie ${ }^{23}$.

În lucrarea de misiune a Bisericii, eficacitatea mărturiei creştine se traduce ca memorie vie a Bisericii. Prin mărturie, capacitatea persuasivă a mesajului evanghelic devine, cu adevărat, o energie reală a actului de credinţă creştină. Acest model tebuie să redefinească mărturia în cadrul misiunii şi să-1 determine pe tot omul postmodern să-şi recâştige calitatea de membru viu al Bisericii celei Adevărate²

${ }^{21}$ Saint Jean Chrysostome, Discours sur Babylas, „Sources Chrétiennes”, Introduction, texte critique, traduction et notes par Margaret A. Schatkin, Paris, Les Éditions du Cerf, 1990, pp. 46-47.

${ }^{22}$ Saint Cyprien de Carthage, op.cit., p. 192.

${ }^{23}$ Ciprian Ioan Streza, Sfânta Euharistie-Hrană vieţii veşnice şi putere a predării întregii existenţe lui Dumnezeu, în „Eucharist and Martyrdom, From The Ancient Catacombs to the Communist Prisons", vol. I, 6-8 may, Alba Iulia, Editura Reîntregirea, 2014, p. 285.

${ }^{24}$ Mihai Himcinschi, Martyria creştină în societatea postmodernă, în „Eucharist 


\section{Euharistia - Jertfa Vieţii}

Hristos-Paştile este Cel Care dă sens Euharistiei şi ne permite nouă, oamenilor, să înţelegem această taină ca prezență, memorial şi comuniune. Încă din primele veacuri, creştinii fac legătura între Euharistie şi Paşti, înţelese ca mistere ale morţii, învierii şi înălţării. Euharistia este locul unde se realizează comuniunea vieţii dintre Dumnezeu şi oameni. Prin împărtăşirea cu Trupul şi Sângele lui Hristos Cel Înviat, creştinul se lasă abandonat Lui, devenind un adevărat mădular al trupului tainic, Biserica. Această pâine a vieţii acţionează ca un ferment care taie toate păcatele şi edifică Trupul lui Hristos, adică Biserica ${ }^{25}$.

Euharistia este cu adevărat un ritual de hrănire. Din antichitate, şi cu precădere din lumea semitică, omul a dat alimentelor valoare sacră şi a înţeles că ele sunt, de fapt, nişte daruri generoase din partea divinităţ̧ii, care sunt lăsate pentru a ne întreţine viaţa. Pâinea, vinul, apa, fructele sunt prinoase pe care Dumnezeu le-a binecuvântat. Mâncarea însăşi are valoare religioasă, deoarece ea aşază oamenii împreună la masă şi stabileşte atât legătura între meseni, cât şi legătura lor cu Dumnezeu, devenind co-meseni ai sacralităţiii ${ }^{26}$. Pâinea frântă este Carnea sau Trupul lui Hristos, iar „El este viaţa noastră veşnică ${ }^{227}$; Euharistia este o taină care comunică viaţa: „Vă uniţi întru aceeaş̧i credinţă ... într-o comuniune deplină, frângând aceeaşi pâine care este calea spre viaţa veşnică, medicament al nemuririi şi viaţă intru Hristos pentru totdeauna"28.

and Martyrdom, From The Ancient Catacombs to the Communist Prisons", vol. I, 6-8 may, Alba Iulia, Editura Reîntregirea, 2014, p. 243.

${ }^{25}$ Raymond Winling, La Résurrection et l'Exaltation du Christ dans la littérature de l'ère patristique, Théologies, Paris, Les Éditions du Cerf, 2000, pp. 408-413. ${ }^{26}$ Xavier Leon-Dufour, Dizionario di Teologia Biblica, Edizione italiana completamente rifusa sulla II edizione francese riveduta e ampliata, a cura di Giovanni Viola e Ambretta Milanoli, V Edizioni, Casa Editrice Marietti, 1990, p. 362.

${ }^{27}$ Saint Ignace D’ Antioche, Ad. Magn. 1, 2; „Sources Chrétiennes”, Texte grec, introduction, traduction et notes de P. Th. Camelot, Paris, Éditions du Cerf, 1951, p. 53.

${ }^{28}$ Ignace D’ Antioche, Ad. Ephes. 20, 2; op.cit., p. 54. 
Trupul şi Sângele lui Hristos nu sunt doar nişte simboluri, ci sunt realităţi ale unei lumi eshatologice în care este şi trăieşte Hristos. Euharistia îi oferă creştinului contactul personal şi palpabil cu Hristos Cel Înviat. Cele două elemente (pâinea şi vinul) din care omul se împărtăşeşte îşi schimbă esenţa devenind adevărată pâine îngerească: „Ş̧i a plouat peste ei mană de mâncare şi pâine cerească le-a dat lor; pâine ingerească a mâncat omul; bucate le-a trimis lor din destul." (Psalm 77, 28-29). Euharistia este adevărata mâncare eshatologicăă Teodor al Mopsuestiei se numără printre antiohienii care a vorbit cel mai clar despre tema euharistică, ca hrană a nemuririi: „El se numeşte pe Sine Însuşi pâinea vieţii, coborâtă din cer, voind să spună: cu adevărat, Eu sunt pâinea vieţii care oferă celor ce cred în Mine nemurirea, cu ajutorul acestui corp văzut, pentru care Eu am coborât din cer şi căruia i-am dăruit nemurirea şi prin mijlocirea căruia Eu dăruiesc celor ce cred in Mine nemurirea"30. Euharistia este în noi sursa unei tensiuni tainice date de darul nemuririi binecuvântate: „Noi nu trebuie să ne mai îndoim că vom primi şi nemurirea mâncând pâinea sacramentală, întrucât, chiar dacă pâinea nu are o astfel de fire, totuşi, când pâinea primeşte pe Duhul Sfânt şi harul care vine de la El, ea devine capabilă să ducă pe cei care o mănâncă la bucuria nemuririi”’’1.

Sfầntul Ioan Gură de Aur vorbeşte în Omiliile sale despre pâinea vieţii, care nu este o pâine obişnuită, ci o pâine coborâtă de sus: „Vi s-a făgăduit odinioară şi vi s-a arătat atunci in chip, iar acum e prezentă şi împlineşte făgăduinţa făcută vouă. Sunt pâine a vieţii, nu pâinea trupească, care desfiinţează numai pătimirea foamei şi eliberează numai trupul de moartea venită din lipsa ei, ci ea este cea care eliberează intreg omul spre viața veşnică şi arată desăvârşit pe omul făcut pentru viaţa veşnică ${ }^{\longmapsto 32}$.

${ }^{29}$ Xavier Leon-Dufour, op.cit., p. 366.

${ }^{30}$ Teodor al Mopsuestiei, Omilii Catehetice, Omilia XV, 11; trad. Ion V. Paraschiv, Cluj-Napoca, Editura Renaşterea, 2008, p. 176.

${ }^{31}$ Ibidem.

${ }^{32}$ Sfântul Chiril al Alexandriei, Comentariu la Evanghelia Sfântului Ioan, în „P.S.B”, trad. Dumitru Stăniloae, Bucureşti, Editura Institutului Biblic şi de 
Legătura dintre Euharistie şi Înviere este redată prin termenul kyriakè, fiind ziua când se celebrează, de altfel, kyriakon deipnon. Sfântul Iustin Martirul şi Filosoful, după ce descrie o sărbătoare euharistică, adaugă: „Iar în ziua soarelui, noi ne adunăm cu toţii laolaltă, deoarece aceasta este prima zi în care Dumnezeu, schimbând intunericul şi materia, a creat lumea, iar Iisus Hristos, Mântuitorul nostru, în aceeaşi zi a înviat din morţi” ${ }^{33}$.

Clement Alexandrinul aminteşte în Pedagogul tema pâinii vieţii, spunând că: „Rolul tainic al pâinii, căci aşa o numeşte Hristos, este trup ca unul care s-a inălţat prin foc, cu alte cuvinte ca cel ce se inalță din stricăciune şi sămânță prin foc şi care este alcătuit prin foc spre bucuria Bisericii, ca o pâine coaptă. Trupul este îmbibat cu sânge, dar sângele este infătişat prin vin. Deci trebuie să ştim că pâinea înmuiată absoarbe vinul, iar apa este lăsată deoparte. Aşa şi trupul Domnului, pâinea cerurilor, absoarbe sângele ca să hrănească pentru nestricăciune pe oamenii cerești, lăsând pieirii numai poftele trupeş̧ti’’34.

Iisus Hristos Cel mort şi Înviat este prezent în starea de jertfã pe Sfânta Masă în Altarul fiecărei biserici, iar Sfânta Liturghie este o jertfă ce reactualizează jertfa istorică de pe Cruce, în calitatea de dovadă a iubirii supreme, manifestată în şi prin Biserică. Unirea şi prefacerea celor două elemente (pâine şi vin în Trupul şi Sângele Domnului) se realizează doar în Biserică, iar în acest sens, Euharistia este singura care are valoare eshatologică în faţa lui Dumnezeu.

\section{Concluzii}

Prin sacrificiul propriei vieți, martirii confirmă faptul că relația lor cu Hristos era pentru ei mai importantă decât supraviețuirea biologică. Ei se numeau mărturisitorii credinței, deoarece martiriul lor

Misiune al Bisericii Ortodoxe Române, 2000, p. 365.

${ }^{33}$ Sfântul Iustin Martirul şi Filosoful, Apologia I, 67; în Apologeţi de limbă greacă, trad. Teodor Bodogae, Bucureşti, Editura Institutului Biblic şi de Misiune al Bisericii Ortodoxe Române, 1997, p. 95.

${ }^{34}$ Clement Alexandrinul, Pedagogul, Ediţie îngrijită de Dumitru Fecioru, Bucureşti, Editura Librăriei Teologice, 1939, p. 71. 
revela credința, adică încrederea lor în vestea cea bună a lui Hristos, iar încrederea nu este posibilă decât ca urmare a unei relații personale. Jertfele martirilor sunt revelarea conţinutului Sfintei Euharistii.

Martirii, prin jertfa vieții lor, se îndreaptă spre Hristos; ei nu se grăbesc spre moarte, ci spre viață, iar pentru ei, a trăi înseamnă Hristos. Martirii nu doresc nici suferința, nici moartea, fiind convinși că merg spre viață, pe care cred că au descoperit-o. Punctul de referință al martirilor nu mai este viața prezentă, ci viața viitoare, și, astfel, se schimbă întreaga ordine a lucrurilor, martiriul devenind în cele din urmă bucurie

Iisus Hristos Cel Mort şi Înviat este prezent în starea de jertfă pe Sfânta Masă, în Altarul fiecărei biserici, iar Sfânta Liturghie este o jertfă ce reactualizează jertfa istorică de pe Cruce, în calitatea de dovadă a iubirii supreme, manifestată în şi prin Biserică. Unirea şi prefacerea celor două elemente (pâinea şi vinul) se realizează doar în Biserică, iar în acest sens, Euharistia este singura care are valoare eshatologică în faţa lui Dumnezeu.

\section{Bibliografie}

1. Autori vari, La prassi del martirio ieri e oggi, Quaderni ASAL, nuova serie, Anno I, numero 3, maggio-giugno, periodico bimestrale della cooperativa „Servizio Missionario”, 1978.

2. Clement Alexandrinul, Pedagogul, Ediţie îngrijită de Dumitru Fecioru, Bucureşti, Editura Librăriei Teologice, 1939.

3. Dufour-Leon, Xavier, Dizionario di Teologia Biblica, Edizione italiana completamente rifusa sulla II edizione francese riveduta e ampliata, a cura di Giovanni Viola e Ambretta Milanoli, V Edizioni, Casa Editrice Marietti, 1990.

4. Eusèbe de Césaré, Histoire Ecclésiastique, Sources Chrétiennes, No 41, Livres V-VII, Traduction et notes par Gustave Bardy, Paris, Les Éditions du Cerf, 1955.

5. Himcinschi, Mihai, Martyria creştină în societatea postmodern, în „Eucharist and Martyrdom, From The Ancient Catacombs 
to the Communist Prisons", vol. I, 6-8 may, Alba Iulia, Editura Reîntregirea, 2014.

6. Holmes W., Michael, The Apostolic Fathers in English, Grand Rapids, MI: Baker Academic.

7. Ică, Ioan I.jr, Canonul Ortodoxiei, Canonul apostolic al primelor secole, I, Sibiu, Editura Deisis, 2008.

8. Larchet, Jean Claude, Sfârş̧it creştinesc vieţii noastre, fără durere, neînfruntat, în pace..., trad. Marinela Bojin, Bucureşti, Editura Basilica a Patriarhiei Române, 2012.

9. Les Constitutions Apostoliques, în „Sources Chrétiennes”, No 329, Tome II (Livres III-VI), Introduction, texte critique, traduction et notes et index par Marcel Metzger, Paris, Les Éditions du Cerf, 1986.

10. Rahner, Karl, Vorgrimler, Herbert Dizionario di Teologia, Edizione italiana a cura di Giuseppe Ghiberti e Giovanni Ferretti, by HerderRoma, 1968.

11. Saint Cyprien de Carthage, La bienfaisance et les aumônes, Sources Chrétiennes, Introduction, texte critique, traduction par Michel Poirier, Paris, Les Éditions du Cerf, 1999.

12. Saint Ignace D' Antioche, Ad. Magn. 1, 2; „Sources Chrétiennes”, Texte grec, introduction, traduction et notes de P. Th. Camelot, Paris, Éditions du Cerf, 1951.

13. Sf. Iustin Martirul şi Filosoful, Apologia I, 67; în „Apologeţi de limbă greacă", trad. Teodor Bodogae, Bucureşti, Editura Institutului Biblic şi de Misiune al Bisericii Ortodoxe Române, 1997.

14. Saint Jean Chrysostome, Discours sur Babylas, Sources Chrétiennes, Introduction, texte critique, traduction et notes par Margaret A. Schatkin, Paris, Les Éditions du Cerf, 1990.

15. Sfântul Chiril al Alexandriei, Comentariu la Evanghelia Sfântului Ioan, în „P.S.B”, trad. Dumitru Stăniloae, Bucureşti, Editura Institutului Biblic şi de Misiune al Bisericii Ortodoxe Române, 2000.

16. Sobco, Laurentius, Noul Martiriu: un scurt moment de eroism sau un mod de viață, în „Eucharist and Martyrdom, From the Ancient Catacombs to the Communist Prisons", Alba Iulia, 6-8 may, Editura Reîntregirea, 2014.

17. Streza, Ciprian Ioan, Sfânta Euharistie - Hrană vieţii veşnice şi putere a predării întregii existenţe lui Dumnezeu, în „Eucharist and Martyrdom, From The Ancient Catacombs to the Communist 
Prisons", vol. I, 6-8 may, Alba Iulia, Editura Reîntregirea, 2014.

18. Teodor al Mopsuestiei, Omilii Catehetice, Omilia XV, 11; trad. Ion V. Paraschiv, Cluj-Napoca, 2008.

19. Théodoret de Cyr, Thérapeutique des maladies helléniques, în „Sources Chrétiennes", No 57. 2, Tome II (Livres VII-XII), Texte critique, traduction, notes et index par Pierre Canivet, Paris, Les Éditions du Cerf, 2001.

20. Winling, Raymond, La Résurrection et l'Exaltation du Christ dans la littérature de l'ère patristique, Théologies, Paris, Les Éditions du Cerf, 2000.

21. Yannaras, Christos, Contra Religiei, trad. Tudor Dinu, București, Editura Anastasia, 2011.

\section{Surse Web:}

1. Didascalia Apostolorum, http://www.bombaxo.com/didascalia.html (accesat în 28. 06.2015).

2. Wehr, Kathryn, The Orthodox Bioethics of Cremation in http:// www.orthodoxytoday.org/OT/view/wehr-the-orthodox-bioethics-ofcremation (accesat în 29.06.2015). 